\title{
Quality of Grain Maize Stored in Gombisa and Sacks in Selected Districts of Jimma Zone, Ethiopia
}

\author{
Dubale Befikadu ${ }^{1}$, Waktole Sori ${ }^{2}$, Solomon Abera ${ }^{3}$, Geremew Bultosa ${ }^{4,5^{*}}$, \\ and Sethumadhavarao $\mathbf{G}^{2}$
}

\author{
${ }^{1}$ Jimma Agricultural Mechanization Research Centre, Jimma, Ethiopia \\ ${ }^{2}$ College of Agriculture and Veterinary Medicine, Jimma University, P.O. Box: 307, Jimma, Ethiopia \\ ${ }^{3}$ School of Natural Resource and Environmental Engineering, Haramaya University, P.O. Box: 138, \\ Dire Dawa, Ethiopia \\ ${ }^{4}$ Department of Food Science and Postharvest Technology, Haramaya University, P.O. Box: 138, \\ Dire Dawa, Ethiopia \\ ${ }^{5}$ Department of Food Science and Technology, Botswana College of Agriculture, P.O. Bag: 0027, \\ Gaborone, Botswana
}

\begin{tabular}{|c|c|}
\hline Abstract & Article Information \\
\hline \multirow{3}{*}{$\begin{array}{l}\text { Quality of maize grains (Variety: Bako Hybrid-660, BH-660) stored in two storage } \\
\text { containers (Gombisa and Sacks) for } 180 \text { days was studied in two agro-ecologies: } \\
\text { intermediate (IAE)- and lowland (LAE) of Jimma zone, Ethiopia. Crude protein, crude } \\
\text { fat, dry matter, total carbohydrate and ash contents were influenced significantly by } \\
\text { storage periods in Gombisa ( } p<0.05) \text {. Crude fat under LAE and ash under both agro- } \\
\text { ecologies were also influenced by storage days }(p<0.05) \text {. There was a significant } \\
\text { ( } p<0.05) \text { effect of storage containers on dry matter and total carbohydrates in the IAE } \\
\text { whereas in LAE appeared insignificant }(p>0.05) \text {. Grains stored in Gombisa under IAE } \\
\text { showed significantly lower dry matter and total carbohydrate contents than in Sacks. } \\
\text { The study showed maize grain quality deteriorations in Gombisa because of favorable } \\
\text { moisture, relative humidity and temperature conditions for maize weevil (Sitophillus } \\
\text { zeamais) and angoumois grain moth (Sitotroga cerealella) attacks during } 180 \text { days of } \\
\text { storage. }\end{array}$} & $\begin{array}{ll}\text { Article History: } \\
\text { Received }: 04-07-2015 \\
\text { Revised }: 15-09-2015 \\
\text { Accepted }: 23-09-2015\end{array}$ \\
\hline & $\begin{array}{l}\text { Keywords: } \\
\text { Agro-ecologies } \\
\text { Chemical composition } \\
\text { Gombisa } \\
\text { Maize grain quality } \\
\text { Sack }\end{array}$ \\
\hline & $\begin{array}{l}\text { "Corresponding Author: } \\
\text { Geremew Bultosa } \\
\text { E-mail: } \\
\text { geremewbultosa@gmail.com } \\
\text { gbultosa@bca.bw }\end{array}$ \\
\hline
\end{tabular}

\section{INTRODUCTION}

Various studies undertaken in sub-Saharan Africa to estimate maize (Zea mays L.) grain losses in traditional storage practices have shown that the losses are generally high. From harvest to consumer market, maize grain postharvest losses in Africa are estimated to range 14 to $36 \%$ (Tefera et al., 2011a; Tefera, 2012). In Ghana, about $15 \%$ of maize grains harvested are lost annually due to attacks by maize weevils (Sitophilus zeamais) (Baidoo et al., 2010). One in five $\mathrm{kg}$ of grain produce in sub-Saharan Africa is estimated to be lost by pest infestations and associated grain decays/spoilage of which maize grain loss remained the highest (FAO/NRI, 2011). In Nigeria, Kerstin et al. (2010) reported 10 to $12 \%$ loss of maize grains stored in traditional storage containers similar to Gombisa due to insect pests. Loss of about $18 \%$ was also reported by the same author in other African countries for maize grain stored in polypropylene sacks for the storage periods of six months.

Maize is one of the most important staple food and cash crops in Ethiopia providing calories for the consumers and income for the traders. In terms of grain volume productions (64.9 million quintals, 25.8\%) and area of cultivation (1.99 million hectares, $16.1 \%$ ) maize stands $1^{\text {st }}$ and $2^{\text {nd }}$, respectively among cereal grains produced in Ethiopia (CSA, 2013/14). Traditionally, maize grain is stored both in- and outdoors by Ethiopian farmers for consumption and to sell in the later months of the year depending on the quantity produced per household. Survey conducted in three major grain producing areas of Ethiopia viz. Hetosa, Ada and Bako indicated that majority of farmers $(93.3 \%)$ are using various traditional grain storage containers that expose their stored grains to be attacked by storage pests and other factors that contribute to deteriorations whereby per house hold grain losses of $12 \%$ was estimated from the total grain produced (Abebe and Bekele, 2006). Eticha (1999) reported an annual maize grain loss in Ethiopia in the range between 2 and $30 \%$. In Jimma Zone, quantitative average maize grain storage loss of 41.0 to $80.0 \%$ and on average $64.5 \%$ of grain damage was estimated in 2004 from fifty traditional farm stores within three to six months of which maize 
Dubale Befikadu et alo,

weevil (Sitophilus zeamais) followed by angoumois grain moth (Sitotroga cereallela (O), rice weevil (Sitophilus oryzae) and flour beetle (Tribolium confusum) were identified as major storage pests (Sori and Ayana, 2012).

In Jimma zone, like in other regions of Ethiopia, there have been some efforts to support post harvest grain management through promotion and demonstration of improved storage structures by the Office of the Ministry of Agriculture and Rural Development (Befikadu, 2011). However, the use of hermetic storage like metal silos (SDC, 2008; Tefera et al., 2011a; De Groote et al., 2013) is not promoted for use by subsistent grain farmers. Thus, grain deterioration problems (both quality and quantity) haven't been solved. Grain storage containers being used by majority of the farmers in the zone (more than 97\%) are traditional ones (Gombisa for maize cobs and Sacks for shelled maize grains) that couldn't protect the stored grain from deterioration (Kemeru, 2007). Maize weevil and angoumois grain Moth were identified in this work as the major insect pests that attacks maize grains during 180 days of storages in both Gombisa and Sacks (Befikadu et al., 2012). In view of limited information, in this paper the extent of maize grain nutrient quality losses in the two traditional storage containers (Gombisa and Sacks) over 180 storage days for two maize growing agro ecologies (IAE and $L A E$ ) are reported.

\section{MATERIALS AND METHODS}

\section{Description of the Study Area}

This study was carried out in Jimma zone, Ethiopia which is found at about $345 \mathrm{~km}$ from Addis Ababa in South west and lies between $36^{\circ} 10^{\prime} \mathrm{E}$ longitude and $7^{\circ}$ 40 ' $\mathrm{N}$ latitude. The zone has an elevation ranging from 880 to $3360 \mathrm{masl}$. The area experiences annual average rainfall of $1000 \mathrm{~mm}$ for 8 to 10 months. The main rainy season extends from May to September and the small rainy season takes place in February, March and April. The temperature of Jimma zone varies from $8-28^{\circ} \mathrm{C}$. The average annual temperature is $20^{\circ} \mathrm{C}$ (Haile and Tolemariam, 2008).

The agro-ecologies of the study area have an altitude range of 1000-1500 (lowlands), 1500-2500 (intermediate) and 2500-3360 masl (highlands) (FAO, 2009). Only two agro-ecologies (intermediate and lowlands) growing $\mathrm{BH}$ 660 maize variety were selected for the study since $\mathrm{BH}$ 660 maize variety is not produced in the highland agroecology of the study area.

\section{Experimental Design}

Factorial arrangement using Completely Randomized Design (CRD) was employed for the experiment in two replications. The factors were: traditional maize storage containers at two levels (Gombisa and Sack), agroecologies at two levels (intermediate and lowland) and storage periods at four levels (immediately after harvest, 60,120 and 180 days after storage). Data were collected at every two months interval, including at the start of the study making up four levels for the factor storage period.

\section{Experimental Materials}

The experimental materials used for the study were $\mathrm{BH}-660$ variety of maize grain harvested in December 2009 and two types of traditional maize storage containers; Gombisa and Sacks (Befikadu et al., 2012).
Sci. Technol. Arts Res. J., July-Sep 2015, 4(3): 26-31

\section{Sampling of the Grain for Evaluation}

Initial sample of six cobs were randomly taken before the bulk was loaded in to storage container, Gombisa, shelled manually to make $1 \mathrm{~kg}$ and was then kept in an air-tight plastic bag. The initial maize samples from each storage containers were taken as a control at the beginning of the storage. Three cobs were drawn from each cage via the tube using strings, shelled manually and thoroughly mixed. Of these samples collected from each Gombisa and Sack, $200 \mathrm{~g}$ were kept in clean airtight plastic bag in a refrigerator until required for analysis. For sampling grain from the Sacks, procedure described in AOAC (1995) was followed.

\section{Chemical Analysis of Maize Grain}

The chemical composition analyses on the maize grain samples collected was done using standard analytical procedures (AACCI, 2000): crude protein (AACCI Method 46-11A), crude fat (AACCl Method 30-25), dry matter (AACCI Method 44-15A), ash (AACCI Method 08-0) and free fatty acid (AACCI Method 02-01A). Total carbohydrate was determined by difference (Monro and Burlingame, 1996).

\section{Data Analysis}

Statistical analysis was performed on the chemical composition data collected over the storage periods using ANOVA and SPSS Version 16.0. Means were compared for the significant differences by LSD test, and significance was accepted at $5 \%$.

\section{RESULTS AND DISCUSSION}

Effect of Storage Periods on Chemical Composition of Maize Grain Stored Under Intermediate (IAE) and Lowland (LAE) Agro-ecologies

The results on chemical composition (crude protein, crude fat, dry matter, total carbohydrate, ash and free fat acid contents) evaluated for $\mathrm{BH}-660$ maize grains stored in Gombisa and sacks under intermediate and lowland agro-ecologies over 180 days (Tables 1, 2 and 3) are discussed below.

Crude protein: The crude protein content of maize grain stored in Gombisa was significantly influenced over the storage durations $(p<0.05)$ (Table 1$)$. Maximum crude protein content was observed at 60 days after storage which was statistically at par with initial storage period and 120 days after storage. Significantly different and minimum crude protein content was recovered at 180 days after storage. However, crude protein content was not significantly $(p>0.05)$ different for grains stored in Sacks. The range of moisture $(\mathrm{M})$, temperature $(\mathrm{T})$ and relative humidity $(\mathrm{RH})$ recorded (Befikadu et al., 2012) under IAE (Gombisa: $\mathrm{M}=9.2$ to $13.2 \%, \mathrm{~T}=18.5$ to $30.2^{\circ} \mathrm{C}$ and $\mathrm{RH}=30.8$ to $54.7 \%$; Sacks: $\mathrm{M}=11.7$ to $13.5 \%, \mathrm{~T}=15.0$ to $28.8^{\circ} \mathrm{C}$ and $\mathrm{RH}=29.3$ to $65.2 \%$ ) and LAE (Gombisa: $\mathrm{M}=9.2$ to $14.6 \%, \mathrm{~T}=21.3$ to $35.0^{\circ} \mathrm{C}$ and $\mathrm{RH}=39.2$ to $51.0 \%$; Sacks: $\mathrm{M}=12.3$ to $13.6 \%, \mathrm{~T}=16.6$ to $29.0^{\circ} \mathrm{C}$ and $\mathrm{RH}=29.8$ to $62.3 \%$ ) are suitable (FleuratLessard, 2004) for grains attack by maize weevil (Sitophillus zeamais) and angoumois grain Moth (Sitotroga cerealella) during 180 days of storage. The difference in the crude protein content decrease could be due to maize weevils and Angoumois grain Moth attacks degree difference with the storage period increase. Both maize weevil (Tefera et al., 2011b; Osipitan et al., 2012; Keba and Sori, 2013) and angoumois grain Moth (Tefera 
Dubale Befikadu et al.,

et al., 2011b) were known to cause substantial nutrient loss in maize grains on storages.

Crude Fat: The crude fat content of maize grain under intermediate agro-ecology in the two storage containers was found not significantly different over six months storage period $(p<0.05)$ (Table 1$)$. However, significant decrease in the crude fat content was observed for maize grain stored under lowland agro-ecology in both Gombisa and Sack (Table 2). Maximum crude fat contents were recorded from initial loading day samples and a decreasing trend in the crude fat content was observed as the storage period progressed from 60 to 180 days. Reduction in crude fat content with increased storage time could be due to attacks by maize weevils (Sitophillus zeamais) and angoumois grain Moth (Sitotroga cerealella) as observed in the study of Watson (1987).

Dry Matter: A significant differences on the dry matter contents was observed under both agro ecologies for grains stored in Gombisa than for grains stored in Sacks. The data for Gombisa remained unchanged up to four months but indicated a significant $(p<0.05)$ reduction at six months of the storage period. Grains sampled from Sacks however showed no significant $(p>0.05)$ difference over the six months of storage periods. Reduction in the dry matter content is at large due to consumption of parts of the grains by insect pests (Tefera et al., 2011b; Befikadu et al., 2012) that decreased the carbohydrate, crude protein and crude fat contents.

Free Fatty Acid: No significant $(p<0.05)$ difference was observed in terms of free fatty acid values for grains stored in Gombisa and Sacks in both agro-ecology (Tables 1 and 2). An increase in the free fatty acidity is related to the degree to which fatty tissues (at large maize germ and aleurone layer) are attacked and release free fatty acids by hydrolysis due to pest actions and moist condition of the grain handling (Eldrid et al., 1995; Sánchez-Mariñez et al., 1997). The free fatty acids content in this work had remained not significant different from initial loading day is probably related to the decrease in the moisture contents of the grains as storage progressed to 180 days in both storage containers under both agro ecologies (Befikadu et al., 2012) and by the relative limited fatty tissue attacks by pests.

Total Carbohydrate: For grains stored in Gombisa under both agro ecologies the total carbohydrate content had decreased significantly throughout the storage time $(p<0.05)$ (Tables 1 and 2$)(p<0.05)$. Whereas for grains stored in Sacks no significant difference were observed even though the result showed a decreasing trend. The difference between the two storages could be attributed to the fact that Gombisa was located out door and thus is more susceptible to insect attacks than the Sack which is stored in house. Moreover, Gombisa has high potential to favor suitable microclimate (temperature, grain moisture content, oxygen concentration and food availability) for maize weevil populations to increase (Fleurat-Lessard, 2004; Ileleji et al., 2007) because of less dense grain packing nature into the Gombisa structure. For example oxygen concentration cannot be depleted fast as that for Sacks.

Ash content: The ash content of the stored grains under both agro-ecologies in both Gombisa and Sack were increased with increase in the storage period (Tables 1
Sci. Technol. Arts Res. J., July-Sep 2015, 4(3): 26-31

and 2). The initial values were $0.96 \%$ and $0.93 \%$ for Gombisa and Sack respectively. The values increased significantly $(p<0.05)$ to $2.45 \%$ and $2.42 \%$ for grains stored in Gombisa and Sacks respectively after two months and further rose to over $2.80 \%$ in the following two months. No significant increment was observed at the end of the last two months in both storage types. The explanation for rise in the ash content could be the cumulative effect of the reduction in the carbohydrate, protein and crude fat contents due to increase in the insect pests attacks (Befikadu et al., 2012) and leaving mineral rich pericarp proportion of the grain proportionally to be large. The result obtained by Lemessa et al. (2000) is supportive to this study showing significant increment in ash content as storage period increased.

\section{Effect of Storage Type on Chemical Composition of Maize Grain}

Data on the effect of storage type on chemical composition of maize grain under intermediate and lowland agro-ecologies are presented in Table 3 . Significantly $(p<0.05)$ higher value in total carbohydrate content was obtained in Sacks than in Gombisa. The dry matter content in Sacks was also significantly higher than that in the Gombisa. The increase in the ash content was high in Gombisa than in Sacks. However, no significant $(p>0.05)$ difference was obtained on the remaining chemical composition of the grain due to the differences in storage containers. The difference in the carbohydrate, dry matter and ash contents between the two storages could be attributed to the higher rate of insect infestation in Gombisa than in Sack (Befikadu et al., 2012).

Maize weevil and angoumois grain Moth were reported as the major insects pest identified from maize samples under both storages (Befikadu et al., 2012). The BH-660 maize variety is known to be susceptible to maize weevil attacks (Keba and Sori, 2013). The temperature, relative humidity and moisture recorded during the study period in both storage facilities under both agro-ecologies were not preventive to insect pests attacks of maize grains and this study have shown there is a maize grain nutrient losses. There is, therefore, a need to develop cost effective management methods for these insect pest control in maize producing areas of Jimma Zone. This also calls for a multi-directional approach in improving pre- and postharvest maize grain handling activities including harvesting, pre-storage drying, storage methods and their management. Identification and test of improved storage containers like hermetic grain storage facilities (rodent proof metal silos and impervious plastic drums) which were proved to be useful for subsistent maize farmers (SDC, 2008; Tefera et al., 2011a; Yakubu, 2012; De Groote et al., 2013) might be an alternative wayforward to extended maize grain storage periods and to preserve maize grain quality in the region. Currently the metal silo usage in Ethiopia are at the demonstration stages. Upgrading of farmers knowledge through education toward various grain quality management skills like adequate maize grain drying before storage, grain cleaning and inspection can also help to reduce the maize grain losses of the region and contributes toward elimination of mycotoxins risks and to improved food security. Such action also reduces the problem of pesticide residues of health risks, since the frequency of pesticide usage on maize storage can be at least minimized if not at all eliminated. 

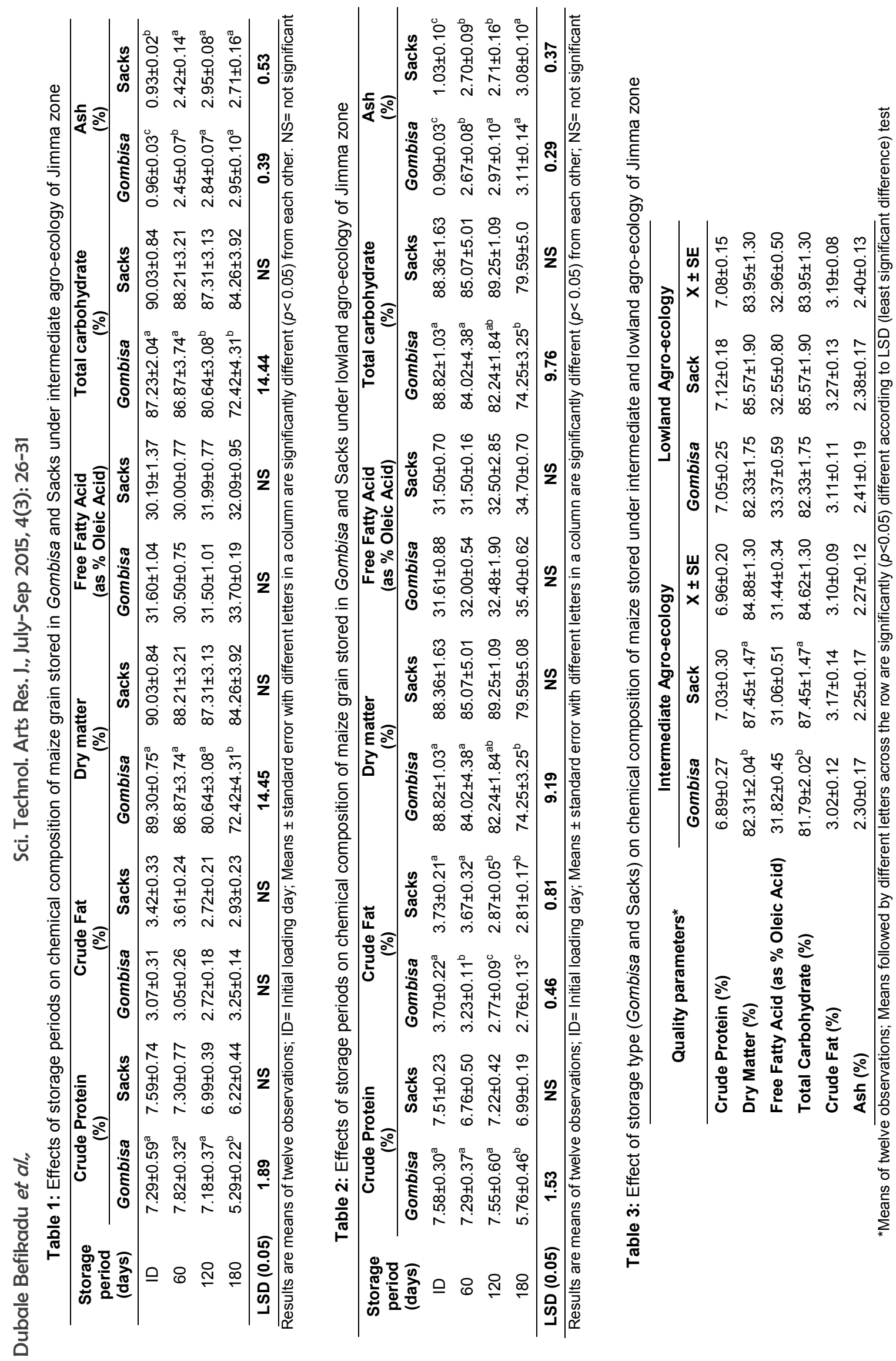


\section{CONCLUSIONS}

The study showed that grain stored in Gombisa exhibited a significant $(p<0.05)$ reduction in the dry matter and total carbohydrate contents with storage period increase. The dry matter and total carbohydrate content had decreased from 89.3 and $88.8 \%$ to 72.4 and $72.4 \%$, respectively by the end of the six months storage period. Similarly the protein content of maize stored in Gombisa dropped from 7.58 to $5.29 \%$ in the same period which is also significant $(p<0.05)$. The ash content showed an overall increase of $2 \%$ while in storage which is significant $(p<0.05)$. Similar changes recorded in grains that were stored in Sacks under both agro-ecologies were all not significant $(p>0.05)$. The study showed that there is a considerable nutrient losses for maize grains stored in Gombisa, particularly the losses are high after 120 days of storage. Both storage containers investigated in this study are not able to prevent maize grain damages as the storage period extends for more than four months. Therefore, maize grains should not be stored for more than four months under intermediate and low land agroecologies as nutritional quality progressively get reduced in such storage facilities. Adoption of improved storage facilities like metal silos and education of farmers on postharvest grain quality management skills will reduce maize grain losses, safe the resources (land, water, labor, seed, fertilizer and other inputs) required for maize grain production, minimizes: the maize nutrient quality deteriorations, mycotoxins and pesticide residues caused health risks and ultimately contributes to the improvement of food safety and food security of the region.

\section{Conflict of Interest}

Conflict of Interest none declared.

\section{Acknowledgements}

Authors acknowledge the financial support of Oromia Agricultural Research Institute (OARI). Authors are also grateful to Jimma University College of Agriculture and Veterinary Medicine (JUCAVM) and Jimma Agricultural Research Center (JARC) for laboratory and logistic supports.

\section{REFERENCES}

AACCI (American Association of Cereal Chemists International). (2000). Approved Methods of the American Association of Cereal Chemists, $16^{\text {th }}$ ed., American Association of Cereal Chemists, St Paul, MN.

Abebe, H.G. and Bekele, H. (2006). Farmers' post-harvest grain management choices under liquidity constraints and impending risks: Implications for achieving food security objectives in Ethiopia. Poster Paper Presented at International Association of Agricultural Economists Conference, Gold Coast, Australia, August 12-8.

AOAC (Association of Official Analytical Chemists). (1995). Official Methods of Analysis. Association of Official Analytical Chemists, $16^{\text {th }}$ ed., Vol. 1, INC, Virginia, USA.

Baidoo, P.K., Mochiah, M.B. and Owusu -Akyaw, M. (2010). Levels of infestation on three different portions of the maize cob by the weevil Sitophilus zeamais (Motschulsky). Journal of Science and Technology 30(3): 21-26.

Befikadu, D., Sori, W., Abera, S., Bultosa, G. and Madhav, R.S. (2012). Influence of agro-ecologies, traditional storage containers and major insect pests on stored maize (Zea mays L.) in selected woredas of Jimma Zone. Asian Journal of Plant Sciences 11(5): 226-234.

Befikadu, D. (2011). Management Practices and Quality of Maize Stored in Traditional Storage Containers: Gombisa and Sacks in Selected Districts of Jimma, MSc. Thesis, Haramaya University, Haramaya, Ethiopia.

CSA (Central Statistical Agency). (2013/14). Agricultural Sample Survey for 2013/14: Report on Area and Production of Major Crops for Private Peasant Holdings, Meher Season, Statistical Bulletin No 532, May 2014, Addis Ababa, Ethiopia.

De Groote, H., Kimenju, S.C., Likhayo, P., Kanampiu, F., Tefera, T., Hellin, J. (2013). Effectiveness of hermetic systems in controlling maize storage pests in Kenya. Journal of Stored Products Research 53: 27-36.

Eldrid, L.M., Vogt, G., Nilsson, A. and Frolich, W. (1995). Effects of storage and heat processing on the content and composition of free fatty acids in oats. Cereal Chemistry 72(I): 88-93

Eticha, F. (1999). Insect pests of Farm-stored Sorghum in the Bako Area. PMJE 3 (1 and 2): 53-60.

FAO/NRI (Food and Agriculture Organization of the United Nations and Natural Resources Institute). (2011). Missing Food: The Case of Postharvest Grain Losses in SubSaharan Africa. Report No. 60371-AFR.The International Bank for Reconstruction and Development / The World Bank, NW, USA

FAO (Food and Agriculture Organization of the United Nations), (2009). Agriculture and environment [online]. Rome. http://www.fao.org/ag/AGP/AGPC/doc/Counprof htm. (Accessed on 12 October, 2009).

Fleurat-Lessard, F. (2004). Pest management. In Wrigley, C., H. Corke and C. E. Walker (Eds.) Encyclopedia of Grain Science, Vol. 3., Elsevier Ltd. UK: Oxford., pp: 244-254.

Haile, A. and Tolemariam, T. (2008). The feed values of indigenous multipurpose trees for sheep in Ethiopia: The case of Vernonia amygdalina, Buddleja polystachya and Maesa lanceolata [online]. Livestock Research for Rural Development 20(3), http://www.Irrd.org//rrd20/3/ hail20045.htm. (Retrieved on 12 April 2011).

Ileleji, K.E., Maier, D.E. and Woloshuk, C.P. 2007. Evaluation of different temperature management strategies for suppression of Sitophilus zeamais (Motschulsky) in stored maize. Journal of Stored Products Research, 43: 480488.

Keba, T. and Sori, W. (2013). Differential resistance of maize varieties to maize weevil (Sitophillus zeamais Motschulsky) (Coleoptera: Curculionidae) under laboratory conditions. Journal of Entomology 10(1): 1-12.

Kemeru, D. (2007). Farm Level Survey on Farm Tools and Implements in Jimma and Iluababor Zones: Agricultural mechanization for productivity and sustainable use of the natural resource, Proceedings of the first agricultural mechanization post harvest and food science research completed research forum, Addis Ababa, Ethiopia, June 5-7, pp.177.

Kerstin, H., Ognakossan, K.E., Tonou, A.K., Lamboni, Y., Adabe, K.E. and Coulibaly, O. (2010). Maize Stored Pests Control by PICS-Bags: Technological and Economic Evaluation. $5^{\text {th }}$ World Cowpea Conference in Saly, Senegal, 27 September -1 October 2010.

Lemessa, F., Bultosa, G. and Wakgari, W. (2000). Quality of grain sorghum (Sorghum bicolor (L.) Moench) stored in traditional underground pits: Case studies in two agro- 


\section{Dubale Befikadu et al.,}

climatic zones in Hararghe, Ethiopia. Journal of Food Science and Technology 37(3): 238-244.

Monro, J. and Burlingame, B. (1996). Carbohydrates and related food compounds: INFOODS tagnames, meanings, and uses. Journal of Food Composition and Analysis 9: 100-118.

Osipitan, A.A., Olaifa, O.K. and Lawal, O.A. (2012). Evaluation of proximate composition of maize grains infested by maize weevil (Sitophilus zeamais $L$.) (Coleoptera: Curculionidae). Munis Entomology and Zoology 7(1): 439-445.

Sánchez-Mariñez, R.I., Cortez-Rocha, M.O., Ortega-Dorame, F., Morales-Valdes, M. and Silveira, M.I. (1997). End-use quality of flour from Rhyzopertha dominica infested wheat. Cereal Chemistry 74(4): 481-483.

Sori, W. and Ayana, A. (2012). Storage pests of maize and their status in Jimma Zone, Ethiopia. African Journal of Agricultural Research 7(28): 4056-4060.

SDC (Swiss Agency for Development and Co-operation). (2008). Manual for Manufacturing Metal Silos for Grain Storage, Bern, Switzerland.
Sci. Technol. Arts Res. J., July-Sep 2015, 4(3): 26-31

Tefera, T. (2012). Post-harvest losses in African maize in the face of increasing food shortage. Food Security 4: 267277.

Tefera, T., Kanampiu, F., De Groote, H., Hellin, J., Mugo, S., Kimenju, S., Beyene, Y., Boddupalli, P.M., Shiferaw, B. and Banziger, M. (2011a). The metal silo: An effective grain storage technology for reducing post-harvest insect and pathogen losses in maize while improving smallholder farmers' food security in developing countries. Crop Protection 30:240-245

Tefera, T., Mugo, S. and Likhayo, P. (2011b). Effects of insect population density and storage time on grain damage and weight loss in maize due to the maize weevil Sitophilus zeamais and the larger grain borer Prostephanus truncates. African Journal of Agricultural Research 6(10): 2249-2254.

Watson, S.A. (1987). Structure and composition. pp. 53-82. In: S.A. Watson, P.E. Ramstad (Eds.), Corn chemistry and technology. American Association of Cereal Chemists Inc., St. Paul, MN.

Yakubu, A. (2012). Reducing losses to maize stored on farms in East Africa using hermetic storage. Ph.D Dissertation Submitted to lowa State University, Ames, lowa, USA, pp 270. 